\title{
PENGARUH PEMBERIAN KOMPRES AIR HANGAT TERHADAP NYERI DISMENOREA PADAREMAJA DI WILAYAH PUSKESMAS SIMALANGALAM
}

\author{
Lijah Munthe', Rizki Noviyanti Harahap² \\ Universitas Haji Sumatera Utara, Medan, Indonesia \\ ${ }^{1}$ Lijahmunthe86@ gmail.com, ${ }^{2}$ kikiharahap91@ gmail.com
}

\begin{abstract}
ABSTRAK
Gangguan menstruasi yang sering terjadi pada kebanyakan perempuan adalah dismenorea. Penanganan untuk mengurangi atau menghilangkan nyeri haid (dismenorea) bisa dilakukan dengan terapi nonfarmakoogi yaitu kompres hangat. Penelitian ini bertujuan untuk mengetahui tentang Pengaruh Pemberian Kompres Air Hangat terhadap Nyeri Dismenorea pada Remaja di Wilayah Puskesmas Simangalam Kabupaten Labuhanbatu Utara Tahun 2020.

Penelitian ini menggunakan Quasy Experiment dengan pendekatan one-group pretestposttes design. Penelitian ini telah dilaksanakan pada 01 Agustus 2020 sampai dengan 31 Agustus 2020. Populasi dalam penelitian ini adalah seluruh remaja di Wilayah Puskesmas Simangalam Kabupaten Labuhanbatu Utara sebanyak 2412 orang. Pengambilan sampel menggunakan Purposive sampling berjumlah 15 orang.

Hasil Penelitian didapat bahwa Nyeri Dismenorea pada Remaja sebelum diberikan Kompres Air Hangat di Wilayah Puskesmas Simangalam Kabupaten Labuhanbatu Utara Tahun 2020 adalah sebagian besar nyeri sedang, Nyeri Dismenorea pada Remaja sebelum diberikan Kompres Air Hangat di Wilayah Puskesmas Simangalam Kabupaten Labuhanbatu Utara Tahun 2020 adalah sebagian besar nyeri ringan. hasil uji Paired Sample -Test didapat nilai $p$ - $0,0001<\alpha=0,05$ maka $\mathrm{H}_{0}$ ditolak artinya secara simultan terdapat Pengaruh Pemberian Kompres Air Hangat terhadap Nyeri Dismenorea pada Remaja di Wilayah Puskesmas Simangalam Kabupaten Labuhanbatu Utara Tahun 2020.

Saran dalam penelitian ini kader kesehatan yang ada di Wilayah Puskesmas Simangalam Kabupaten Labuhanbatu Utara turut serta memberikan edukasi tentang pentingnya pemberian kompres hangat dalam pengurangan nyeri.
\end{abstract}

\section{Kata Kunci : Kompres Air Hangat, Nyeri Haid}




\section{PENDAHULUAN}

\subsection{Latar Belakang}

Masa remaja merupakan suatu masa peralihan dari pubertas yang ditandai dengan kematangan organ seksual dan tercapainya kemampuan untuk reproduksi, dimana salah satu ciri dari tanda pubertas seorang perempuan yaitu dengan terjadinya menstruasi. Menstruasi merupakan peluruhan lapisan jaringan endometrium bersama dengan darah, tejadi secara berkala dan dipengaruhi oleh hormon reproduksi. Lamanya perdarahan menstruasi rata- rata berlangsung selama 5-7 hari dengan siklus rata - rata 28 hari (Janiwarti dan Pieter, 2013).

Menstruasi dapat menimbulkan gangguan yang cukup berarti bagi perempuan. Gangguan menstruasi yang sering terjadi pada kebanyakan perempuan adalah dismenorea. Dismenorea merupakan rasa tidak enak di perut bagian bawah sebelum dan selama haid. Dismenorea terjadi karena pelepasan Prostaglandin yang berlebihan mengakibatkan kenaikan kontraksi uterus sehingga terjadi rasa nyeri saat menstruasi (Yunianingrum, 2017).

Menurut World Health Organization (WHO) yang dikutip dalam Silviani dkk (2019) menyebutkan bahwa angka kejadian dismenorea cukup tinggi diseluruh dunia. Rata-rata insidensi terjadinya dismenorea pada wanita muda antara $16,8-81 \%$. Rata-rata di negaranegara Eropa dismenorea terjadi pada $45-97 \%$ wanita. Dengan prevalensi terendah di Bulgaria $(8,8 \%)$ dan tertinggi mencapai $94 \%$ di negara Finlandia. Prevalensi dismenorea tertinggi sering ditemui pada remaja wanita, yang diperkirakan antara 20-90\%. Sekitar 15\% remaja dilaporkan mengalami dismenorea berat. Di Amerika Serikat, dismenorea diakui sebagai penyebab paling sering ketidakhadiran di sekolah yang dialami remaja putri. Selain itu, juga dilakukan survey pada 113 wanita Amerika Serikat dan dinyatakan prevalensi sebanyak 29-44\%, paling banyak pada usia 18-45 tahun (Silviani dkk, 2019).

Di Indonesia angka kejadian dismenorea tipe primer adalah sekitar 54,89\% sedangkan sisanya penderita dengan dismenorea sekunder. Dismenorea terjadi pada remaja dengan prevalensi berkisar antara $43 \%$ hingga 93\%, dimana sekitar 74- 80\% remaja mengalami dismenorea ringan, sementara angka kejadian endometriosis pada remaja dengan nyeri panggul diperkirakan 25-38\%, sedangkan pada remaja yang tidak memberikan respon positif terhadap penanganan untuk nyeri haid, endometriosis ditemukan pada $67 \%$ kasus. Kelainan terjadi pada $60-70 \%$ wanita di Indonesia dengan $15 \%$ diantaranya mengeluh bahwa aktivitas mereka menjadi terbatas akibat dismenore (Nurwana dkk, 2017).

Dismenorea dibagi menjadi dua yaitu dismenorea primer dan dismenorea sekunder. Dismenorea primer adalah menstruasi yang sangat nyeri, tanpa patogis pelvis yang dapat di identifikasi dan dapat terjadi pada waktu menarche atau segera setelahnya. Dismenorea ditandai oleh nyeri keram yang dimulai sebelum atau segera setelah awitan aliran menstruasi dan belanjut selama 48 hingga 72 jam (Dahlan dan Syahminan, 2017).

Dampak dari dismenorea selain menganggu aktivitas sehari - hari dan menurunnya kinerja yaitu mengalami mual, muntah, dan diare. Masih banyak wanita yang menganggap nyeri haid sebagai hal yang biasa, mereka beranggapan $1-2$ hari sakitnya akan hilang. Padahal nyeri haid bisa menjadi tanda dan gejala suatu penyakit misalnya endometritis yang bisa mengakibatkan sulitnya mendapat keturunan (Wiknjosastro dkk, 2014).

Dismenorea banyak dialami oleh wanita yang menstruasi, tetapi banyak pula dari mereka yang sering mengabaikan disminorea tanpa melakukan upaya penanganan yang tepat. Kondisi seperti ini bisa saja membahayakan kesehatan wanita apabila dibiarkan tanpa penanganan. Dismenorea dapat menjadi salah satu gejala endometriosis atau penyakit dismenorea sekunder lainnya, oleh karena itu diperlukan upaya penanganan yang tepat dan benar pada wanita yang mengalami dismenorea terutama usia remaja (Janiwarty dan Pieter, 2013).

Penanganan dismenorea sangat penting untuk dilakukan, terutama pada usia remaja, karena bila tidak ditangani akan berpengaruh pada aktifitas remaja itu sendiri. Banyak remaja 
putri yang belum mengetahui cara penanganan dismenorea. Sehingga menimbulkan masalah bagi remaja tersebut setiap datang haid (Mahua dkk, 2018).

Penanganan untuk mengurangi atau menghilangkan nyeri haid (dismenorea) biasanya dilakukan dengan dua metode yaitu secara farmakologi dan non-farmakologi. Pengobatan farmakologi pada dismenorea dengan menggunakan obat analgetik pada dosis biasa mempunyai efek samping antara lain mual, muntah, konstipasi, kegelisahan dan rasa ngantuk (Dahlan dan Syahminan, 2017). Sedangkan pengobatan non-farmakologis dapat dilakukan dengan terapi komplementer salah satunya yaitu penggunaan kompres hangat (Yunianingrum, 2017).

Kompres hangat merupakan pengompresan yang dilakukan dengan mempergunakan buli-buli panas atau botol air panas yang di bungkus kain yaitu secara konduksi dimana terjadi pemindahan panas dari buli-buli ke dalam tubuh sehingga menyebabkan pelebaran pembuluh darah dan terjadi penurunan ketegangan otot sehingga nyeri haid yang di rasakan akan berkurang atau hilang. Kompres hangat sebagai metode yang sangat efektif untuk mengurangi nyeri (Yunianingrum, 2017). Dampak fisiologis dari kompres hangat adalah pelunakan jaringan fibrosa, membuat otot tubuh lebih rileks, menurunkan atau menghilangkan rasa nyeri, dan memperlancar aliran darah (Nida dan Sari, 2016).

Efek hangat dari kompres dapat menyebabkan vasodilatasi pada pembuluh darah yang nantinya akan meningkatkan aliran darah ke jaringan Penyaluran zat asam dan makanan ke sel-sel diperbesar dan pembuangan dari zat-zat diperbaiki yang dapat mengurangi rasa nyeri haid primer yang disebabkan suplai darah ke endometrium kurang (Nida, 2016). Pemberian kompres hangat memakai prinsip pengantaran panas melalui cara konduksi yaitu perpindahan panas dari buli-buli panas ke dalam perut, sehingga akan menurunkan nyeri pada wanita dengan dismenorea primer, karena pada wanita dengan dismenorea ini mengalami kontraksi uterus dan kontraksi otot polos (Anugraheni dan Wahyuningsih, 2013).

Menurut penelitian yang dilakukan Nida (2016) menyebutkan bahwa kompres hangat berpengarhu terhadap penurunan nyeri dismenorea pada Responden kelas XI di SMK Muhammadiyah Watukelir, dengan nilai $\mathrm{p}$ sebesar $0,000(\mathrm{p}<0,05)$. Hal ini sejalan dengan penelitian yang dilakukan oleh Dahlan dan Syahminan (2017) menyebutkan bahwa kompres hangat dapat menurunkan tingkat nyeri dismenorea pada Responden SMK Perbankan Simpang Haru Padang.

Berdasarkan survey awal yang dilakukan di Wilayah Puskesmas Simangalam Kabupaten Labuhanbatu Utara dengan jumlah remaja sebanyak 2412 orang dengan distribusi remaja yang mengalami nyeri haid (dismenorea) sebanyak 257 orang. Berdasarkan hasil wawancara yang dilakukan kepada 10 orang Responden didapatkan bahwa 5 Responden mengalami nyeri saat menstruasi, 2 Responden mengatakan mengurangi nyeri tersebut dengan minum obat anti nyeri dan 1 mengatakan tiduran di kamar dan diolesi minyak kayu putih, 2 Responden tidak melakukan upaya penanganan, hanya ditahan dan dibiarkan saja.

Mereka mengatakan keadaan ini sangat mengganggu dan membuat malas untuk melakukan aktifitas. Menurut hasil observasi yang dilakukan di Wilayah Puskesmas Simalangalam menyebutkan bahwa responden yang mengalami dismenorea mengeluh sakit perut disertai pusing, lemas dan bahkan ada beberapa Responden yang sampai pingsan ketika benar-benar tidak kuat menahan rasa sakit tersebut.

Berdasarkan hal tersebut di atas, penulis ingin meneliti apakah ada Pengaruh Pemberian Kompres Air Hangat terhadap Nyeri Dismenorea pada Remaja di Wilayah Puskesmas Simangalam Kabupaten Labuhanbatu Utara Tahun 2020.

\section{Perumusan Masalah}

Rumusan masalah dalam penelitian ini adalah apakah ada "Pengaruh Pemberian Kompres Air Hangat terhadap Nyeri Dismenorea pada Remaja di Wilayah Puskesmas Simangalam Kabupaten Labuhanbatu Utara Tahun 2020”. 


\section{Tujuan Penelitian \\ Tujuan Umum}

Tujuan penelitian ini adalah untuk mengetahui tentang "Pengaruh Pemberian Kompres Air Hangat terhadap Nyeri Dismenorea pada Remaja di Wilayah Puskesmas Simangalam Kabupaten Labuhanbatu Utara Tahun 2020".

\section{Tujuan Khusus}

1. Untuk mengetahui Nyeri Dismenorea pada Remaja sebelum diberikan Kompres Air Hangat di Wilayah Puskesmas Simangalam Kabupaten Labuhanbatu Utara Tahun 2020

2. Untuk mengetahui Nyeri Dismenorea pada Remaja sesudah diberikan Kompres Air Hangat di Wilayah Puskesmas Simangalam Kabupaten Labuhanbatu Utara Tahun 2020.

3. Untuk melihat Pengaruh Pemberian Kompres Air Hangat terhadap Nyeri Dismenorea pada Remaja di Wilayah Puskesmas Simangalam Kabupaten Labuhanbatu Utara Tahun 2020.

\section{METODE PENELITIAN \\ Jenis dan Desain Penelitian \\ Jenis Penelitian}

Penelitian ini merupakan penelitian Quasy Experiment yaitu dalah eksperimen yang memiliki perlakuan (treatments), pengukuran-pengukuran dampak (outcome measures), dan unit-unit eksperiment (experimental units) namun tidak menggunakan penempatan secara acak. (Sugiyono, 2014).

\section{Desain Penelitian}

Desain penelitian dengan pendekatan one-group pretest-posttes design yaitu suatu teknik untuk mengetahui efek sebelum dan sesudah pemberian perlakuan (Sugiyono, 2014). Yaitu untuk melihat Perbedaan sebelum dan sesudah diberikan Kompres Air Hangat terhadap Nyeri Dismenorea pada Remaja di Wilayah Puskesmas Simangalam Kabupaten Labuhanbatu Utara Tahun 2020.

\section{Lokasi dan Waktu Penelitian}

\section{Lokasi Penelitian}

Penelitian ini telah dilaksanakan di Wilayah Puskesmas Simangalam Kabupaten Labuhanbatu Utara dengan pertimbangan masih banyaknya remaja yang mengalami dismenorea (nyeri haid) dan tidak mengetahui cara mengurangi nyerinya, belum pernah dilakukan penelitian dengan judul yang sama, adanya populasi dan sampel yang mencukupi, dan adanya refrensi yang mendukung.

\section{Waktu Penelitian}

Penelitian ini akan dilaksanakan pada Bulan Juli sampai dengan Agustus 2020 yaitu mulai melakukan penelusuran kepustakaan, penyusunan skripsi, seminar skripsi, penelitian, analisis data dan penyusunan laporan akhir. Penyebaran kuesioner dilakukan pada bulan Agustus 2020.

\section{Populasi dan Sampel \\ Populasi}

Populasi adalah keseluruhan objek penelitian atau objek yang diteliti (Notoatmodjo, 2010). Populasi dalam penelitian ini adalah seluruh remaja di Wilayah Puskesmas Simangalam Kabupaten Labuhanbatu Utara sebanyak 2412 orang.

\section{Sampel}

Sampel adalah sebagian dari jumlah dan karakteristik yang dimiliki oleh populasi (Notoadmodjo, 2010). Teknik pengambilan sampel menggunakan teknik purposive sampling. Menurut Sugiyono (2014) Purposive sampling adalah teknik penentuan sampel dengan 
pertimbangan tertentu. Alasan menggunakan teknik purposive sampling adalah karena tidak semua sampel memiliki kriteria yang sesuai dengan yang telah penulis tentukan. Oleh karena itu, penulis memilih teknik purposive sampling dengan menetapkan pertimbanganpertimbangan atau kriteria-kriteria tertentu yang harus dipenuhi oleh sampel-sampel yang digunakan dalam penelitian ini.

Sampel penelitian ini diambil dari populasi yang memenuhi kriteria inklusi dan ekslusi sebagai berikut:

1. Kriteria inklusi

Kriteria inklusi adalah karakteristik umum subjek penelitian dari suatu populasi target yang terjangkau dan akan diteliti (Nursalam, 2013). Kriteria inklusi dalam penelitian ini adalah :

a. Remaja berumur antara 12-24 Tahun .

b. Belum pernah dilakukan pengompresan sebelumnya

c. Responden dapat baca tulis, tidak bisu dan tuli

d. Bersedia menjadi responden

2. Kriteria eksklusi

Kriteria eksklusi yaitu menghilangkan atau mengeluarkan subjek yang memenuhi kriteria inklusi dari studi karena berbagai sebab (Nursalam, 2013). Kriteria ekslusi dalam penelitian ini adalah :

a. Responden tersebut menolak dijadikan responden

b. Responden mempunyai penyakit lain bukan karena nyeri haid.

Sampel yang dapat ditetapkan dari total populasi adalah sebanyak 15 orang yang ditentukan berdasarkan pasien telah memenuhi kriteria inklusi dan ekslusi dalam penelitian ini.

\subsection{Hasil Penelitian}

\subsubsection{Karakteristik Responden}

Karakteristik responden yang diteliti dalam penelitian ini meliputi: Umur dan pertama kali haid dapat dilihat pada tabel 4.1 :

Tabel 4.1. Karakteristik Responden di Wilayah Puskesmas Simangalam Kabupaten Labuhanbatu Utara Tahun 2020

\begin{tabular}{clcc}
\hline No & Karakteristik & Frekuensi (f) & Persentase (\%) \\
\hline 1 & Umur Responden & & \\
& 15 Tahun & 3 & 20,0 \\
& 16 Tahun & 8 & 53,3 \\
& 17 Tahun & 4 & 26,7 \\
\hline \multicolumn{2}{l}{ Jumlah } & $\mathbf{1 5}$ & $\mathbf{1 0 0 , 0}$ \\
\hline 2 & Pertama Kali Haid & & \\
& SD & 1 & 6,7 \\
& SMP & 13 & 86,6 \\
& SMA & 1 & 6,7 \\
\hline & Jumlah & $\mathbf{1 5}$ & $\mathbf{1 0 0 , 0}$ \\
\hline
\end{tabular}

Berdasarkan tabel 4.1 dapat dilihat dari 15 orang responden di Wilayah Puskesmas Simangalam Kabupaten Labuhanbatu Utara Tahun 2020 dapat dilihat bahwa umur responden sebagian besar adalah umur 16 Tahun sebanyak 8 orang $(53,3 \%)$, dan responden menyebutkan bahwa pertama kali haid sebagian besar sewaktu SMP sebanyak 13 orang $(86,6 \%)$. 
4.1.2. Distribusi Frekuensi Nyeri Dismenorea pada Remaja sebelum diberikan Kompres Air Hangat di Wilayah Puskesmas Simangalam Kabupaten Labuhanbatu Utara Tahun 2020

Untuk melihat hasil Frekuensi Nyeri Dismenorea pada Remaja sebelum diberikan Kompres Air Hangat di Wilayah Puskesmas Simangalam Kabupaten Labuhanbatu Utara Tahun 2020 dapat dijabarkan pada Tabel 4.2 :

Tabel 4.2 Distribusi Frekuensi Nyeri Dismenorea pada Remaja sebelum diberikan Kompres Air Hangat di Wilayah Puskesmas Simangalam Kabupaten Labuhanbatu Utara Tahun 2020

\begin{tabular}{llcc}
\hline No & $\begin{array}{c}\text { Nyeri Dismenorea pada } \\
\text { Remaja sebelum diberikan } \\
\text { Kompres Air Hangat }\end{array}$ & Frekuensi (f) & \% \\
\hline 1 & Sedang & 8 & 53,3 \\
2 & Berat & 7 & 46,7 \\
\hline & Jumlah & $\mathbf{1 5}$ & $\mathbf{1 0 0}$ \\
\hline
\end{tabular}

Dari tabel 4.2 dapat dilihat bahwa Nyeri Dismenorea pada Remaja sebelum diberikan Kompres Air Hangat di Wilayah Puskesmas Simangalam Kabupaten Labuhanbatu Utara Tahun 2020 adalah sebagian besar nyeri sedang sebanyak 8 orang $(53,3 \%)$.

4.1.3. Distribusi Frekuensi Nyeri Dismenorea pada Remaja sesudah diberikan Kompres Air Hangat di Wilayah Puskesmas Simangalam Kabupaten Labuhanbatu Utara Tahun 2020

Untuk melihat hasil Frekuensi Nyeri Dismenorea pada Remaja sebelum diberikan Kompres Air Hangat di Wilayah Puskesmas Simangalam Kabupaten Labuhanbatu Utara Tahun 2020 dapat dijabarkan pada Tabel 4.3 :

Tabel 4.3 Distribusi Frekuensi Nyeri Dismenorea pada Remaja sebelum diberikan Kompres Air Hangat di Wilayah Puskesmas Simangalam Kabupaten Labuhanbatu Utara Tahun 2020

\begin{tabular}{llcc}
\hline No & $\begin{array}{c}\text { Nyeri Dismenorea pada } \\
\text { Remaja sebelum diberikan } \\
\text { Kompres Air Hangat }\end{array}$ & Frekuensi (f) & \% \\
\hline 1 & Ringan & 11 & 73,3 \\
2 & Sedang & 4 & 26,7 \\
\hline & Jumlah & $\mathbf{1 5}$ & $\mathbf{1 0 0}$ \\
\hline
\end{tabular}

Dari tabel 4.3 dapat dilihat bahwa kategori Nyeri Dismenorea pada Remaja sebelum diberikan Kompres Air Hangat di Wilayah Puskesmas Simangalam Kabupaten Labuhanbatu Utara Tahun 2020 adalah sebagian besar nyeri ringan sebanyak 11 orang $(73,3 \%)$.

4.1.4. Pengaruh Pemberian Kompres Air Hangat terhadap Nyeri Dismenorea pada Remaja di Wilayah Puskesmas Simangalam Kabupaten Labuhanbatu Utara Tahun 2020

Untuk mengetahui Pengaruh Pemberian Kompres Air Hangat terhadap Nyeri Dismenorea pada Remaja di Wilayah Puskesmas Simangalam Kabupaten Labuhanbatu Utara Tahun 2020 dapat dijabarkan pada tabel 4.4 :

Tabel 4.4 Pengaruh Pemberian Kompres Air Hangat terhadap Nyeri Dismenorea pada Remaja di Wilayah Puskesmas Simangalam Kabupaten Labuhanbatu Utara Tahun 2020

\begin{tabular}{ccccc}
\hline No & Perlakuan & Mean & N & Sig. \\
\hline 1 & Nyeri Dismenorea Pre Test & 2,47 & 15 & 0,0001 \\
\cline { 3 - 5 }
\end{tabular}


Berdasarkan Tabel 4.4 di atas dapat dilihat bahwa terdapat perbedaan nilai rata-rata Nyeri Dismenorea pada Remaja sebelum dan sesudah diberikan kompres hangat. Dimana nyeri Dismenorea pada Remaja sebelum diberikan didapat nilai rata-rata sebesar 2,47 yang mengindikasikan bahwa antara nyeri sedang dan berat (indeks $=1=$ nyeri ringan, $2=$ nyeri sedang dan $3=$ nyeri berat). Setelah diberikan kompres hangat terdapat pengurangan nyeri dismenorea dengan rata-rata sebesar 1,27 yang mengindikasikan nyeri antara ringan sampai dengan sedang.

Kemudian berdasarkan hasil uji Paired Sample -Test didapat nilai $p$ - 0,0001< $\alpha=0$, maka $\mathrm{H}_{0}$ ditolak artinya secara simultan terdapat Pengaruh Pemberian Kompres Air Hangat terhadap Nyeri Dismenorea pada Remaja di Wilayah Puskesmas Simangalam Kabupaten Labuhanbatu Utara Tahun 2020.

\section{PEMBAHASAN}

Nyeri Dismenorea pada Remaja sebelum diberikan Kompres Air Hangat di Wilayah Puskesmas Simangalam Kabupaten Labuhanbatu Utara Tahun 2020

Dismenorea merupakan rasa tidak enak di perut bagian bawah sebelum dan selama haid. Dismenorea terjadi karena pelepasan Prostaglandin yang berlebihan mengakibatkan kenaikan kontraksi uterus sehingga terjadi rasa nyeri saat menstruasi (Yunianingrum, 2017). Dismenorea dibagi menjadi dua yaitu dismenorea primer dan dismenorea sekunder. Dismenorea primer adalah menstruasi yang sangat nyeri, tanpa patogis pelvis yang dapat di identifikasi dan dapat terjadi pada waktu menarche atau segera setelahnya. Dismenorea ditandai oleh nyeri keram yang dimulai sebelum atau segera setelah awitan aliran menstruasi dan belanjut selama 48 hingga 72 jam (Dahlan dan Syahminan, 2017).

Dari hasil penelitian didapat bahwa Nyeri Dismenorea pada Remaja sebelum diberikan Kompres Air Hangat di Wilayah Puskesmas Simangalam Kabupaten Labuhanbatu Utara Tahun 2020 adalah sebagian besar nyeri sedang. Berdasarkan hasil wawancara dilapangan terdapat satu orang anak yang merasakan nyeri berat menyebutkan bahwa merasakan nyeri yang menjalar dari perut ke pinggang, rasa mual, pusing dan sakit perut seperti diare.

Nyeri ini disebabkan karena kontraksi otot moimetrium yang berlebihan maka akan mengurangi aliran darah, sehingga kekurangan oksigen dalam sel-sel miometrium yang mengakibatkan timbulnya nyeri pada saat menstruasi spasmodik, nyeri ini menyebabkan perut terasa mulas. Ini terjadi pada semua wanita yang mengalami menstruasi (Lowdermilk, dkk :2013).

Menurut Nida dan Sari (2016) menyebutkan bahwa nyeri dismenorea disebabkan oleh faktor hormonal, yaitu meningkatnya hormon progesteron dan stress dapat menyebabkan nyeri haid. Secara tidak sadar stress dapat membuat penekanan pada pinggul dan otot-otot punggung bagian bawah. Melihat dampak dari nyeri haid tersebut dapat dikatakan bahwa nyeri haid merupakan salah satu problema dalam kehidupan remaja, yang memaksa mereka untuk menggunakan berbagai cara untuk mencegah terjadinya nyeri haid.

Beberapa faktor yang mempengaruhi salah satunya adalah umur. Dimana umur responden sebagian besar adalah 16 tahun. Menurut Dahlan dan Syahminan (2017) menyebutkan bahwa umur merupakan variabel yang mempengaruhi nyeri terutama pada anak dan orang dewasa. Umur juga merupakan salah satu faktor yang mempengaruhi nyeri, semakin besar umur seseorang maka semakin bisa mengendalikan nyeri.

Nyeri Dismenorea pada Remaja sesudah diberikan Kompres Air Hangat di Wilayah Puskesmas Simangalam Kabupaten Labuhanbatu Utara Tahun 2020 
Penanganan untuk mengurangi atau menghilangkan nyeri haid (dismenorea) biasanya dilakukan dengan dua metode yaitu secara farmakologi dan non-farmakologi. Pengobatan farmakologi pada dismenorea dengan menggunakan obat analgetik pada dosis biasa mempunyai efek samping antara lain mual, muntah, konstipasi, kegelisahan dan rasa ngantuk (Dahlan dan Syahminan, 2017). Sedangkan pengobatan non-farmakologis dapat dilakukan dengan terapi komplementer salah satunya yaitu penggunaan kompres hangat (Yunianingrum, 2017).

Berdasarkan hasil penelitian didapat bahwa Nyeri Dismenorea pada Remaja sebelum diberikan Kompres Air Hangat di Wilayah Puskesmas Simangalam Kabupaten Labuhanbatu Utara Tahun 2020 adalah sebagian besar nyeri ringan. Hal ini sejalan dengan Lowdermilk, dkk (2013) dimana nyeri dismenorea dapat berkurang dengan terapi non-farmakologi berupa kompres hangat. Didukung oleh penelitian Sesuai dengan penelitian Bonde, dkk (2014) tentang pengaruh kompres panas terhadap penurunan derajat nyeri haid pada Responden SMA dan SMK Yadika Kopandakan II didapatkan data bahwa rata-rata nyeri haid sesudah diberikan kompres hangat adalah 1,27, nilai terendah adalah skala nyeri 1 (ringan) dan tertinggi adalah skala nyeri 2 (sedang) dari skala $0-4$.

Kompres hangat memberikan rasa hangat pada responden dengan menggunakan cairan atau alat yang menimbulkan hangat pada bagian tubuh yang memerlukannya (Natali, 2013). Kompres hangat efektif untuk menurunkan nyeri dismenore yang dirasakan remaja putri baik dihari pertama menstruasi maupun dihari kedua menstruasi. Pemberian aplikasi hangat pada tubuh merupakan suatu upaya untuk mengurangi gejala nyeri akut maupun kronis (Mahua $\mathrm{dkk}, 2018$ ). Terapi ini efektif untuk mengurangi nyeri yang berhubungan dengan ketegangan otot walaupun dapat juga dipergunakan untuk mengurangi berbagai jenis nyeri yang lain (Mahua dkk, 2018).

Tujuan dari kompres hangat ini untuk menurunkan intensitas nyeri dengan manfaat pemberian kompres hangat secara biologis yang menyebabkan dilatasi pembuluh darah yang mengakibatkan peningkatan sirkulasi darah. Pemberian kompres hangat memakai prinsip pengantaran panas melalui cara konduksi dimana panas ditempelkan pada daerah yang sakit untuk melancarkan sirkulasi darah dan menurunkan ketegangan otot sehingga akan menurunkan nyeri pada wanita dengan dismenore primer, karena pada wanita dengan dismenore ini mengalami kontraksi uterus dan kontraksi otot polos (Anugraheni dan Wahyuningsih, 2013).

Dampak fisiologis dari kompres hangat adalah pelunakan jaringan fibrosa, membuat otot tubuh lebih rileks, menurunkan atau menghilangkan rasa nyeri, dan memperlancar aliran darah (Mahua dkk, 2018). Kompres hangat bermanfaat untuk meningkatkan suhu kulit lokal, melancarkan sirkulasi darah dan menstimulasi pembuluh darah, mengurangi spasme otot dan meningkatkan ambang nyeri, menghilangkan sensasi rasa nyeri, serta memberikan ketenangan dan kenyamanan (Mahua dkk, 2018).

Pengaruh Pemberian Kompres Air Hangat terhadap Nyeri Dismenorea pada Remaja di Wilayah Puskesmas Simangalam Kabupaten Labuhanbatu Utara Tahun 2020

Berdasarkan hasil penelitian dapat dilihat bahwa terdapat perbedaan nilai rata-rata Nyeri Dismenorea pada Remaja sebelum dan sesudah diberikan kompres hangat. Dimana nyeri Dismenorea pada Remaja sebelum diberikan didapat nilai rata-rata sebesar 2,47 yang mengindikasikan bahwa antara nyeri sedang dan berat (indeks $=1=$ nyeri ringan, $2=$ nyeri sedang dan $3=$ nyeri berat). Setelah diberikan kompres hangat terdapat pengurangan nyeri dismenorea dengan rata-rata sebesar 1,27 yang mengindikasikan nyeri antara ringan sampai dengan sedang.

Kemudian berdasarkan hasil uji Paired Sample - Test didapat nilai $p$ - $0,0001<\alpha=0$, maka $\mathrm{H}_{0}$ ditolak artinya secara simultan terdapat Pengaruh Pemberian Kompres Air Hangat 
terhadap Nyeri Dismenorea pada Remaja di Wilayah Puskesmas Simangalam Kabupaten Labuhanbatu Utara Tahun 2020.

Sejalan dengan penelitian Nida dan Sari (2017) yang melakukan penelitian yang berjudul Pengaruh Pemberian Kompres Hangat terhadap Penurunan Nyeri Dismenorea pada Responden Kelas XI SMK Muhammadiyah Watukelir Sukoharjo didapat hasil bahwa penelitian ini menunjukkan adanya pengaruh kompres hangat terhadap penurunan nyeri dismenorea pada Responden kelas XI di SMK Muhammadiyah Watukelir, dengan nilai $\mathrm{p}$ sebesar 0,000 ( $\mathrm{p}<0,05)$.

Didukung oleh penelitian Dahlan dan Syahminan (2017) yang melakukan penelitian yang berjudul Pengaruh Terapi Kompres Hangat terhadap Nyeri Haid (Dismenorea) pada Responden SMK Perbankan Simpang Haru Padang menyebutkan bahwa Kompres hangat dapat menurunkan tingkat nyeri dismenorea pada Responden SMK Perbankan Simpang Haru Padang.

Didukung oleh penelitian Ramadhayanti dkk (2017) yang berjudul Pengaruh Kompres Hangat terhadap Penurunan Derajat Nyeri Haid pada Remaja Putri di SMA Karya Ibu Palembang yang menyebutkan bahwa ada Pengaruh pemberian kompres hangat terhadap penurunan derajat nyeri haid $(\mathrm{p}=0,0001)$.

Didukung oleh penelitian Syahria (2016) dengan judul pengaruh kompres hangat terhadap penurunan nyeri dismenorea pada mahasiswa tingkat akhir IV Bidan Pendidik di Universitas 'Aisyiyah Yogyakarta menyebutkan bahwa Ada pengaruh pemberian kompres hangat terhadap penurunan nyeri dismenore pada mahasiswa tingkat akhir D IV Bidan Pendidik di Universitas 'Aisyiyah Yogyakarta Sebelum diberikan kompres hangat mayoritas responden mengalami nyeri sedang, yaitu 14 responden $(93,3 \%)$. Sedangkan intensitas nyeri dismenore sesudah diberikan kompres hangat paling banyak pada kategori nyeri ringan, yaitu 11 responden $(73,3 \%)$. Hasil uji analisis dengan Wilcoxon significancy p sebesar 0,001 $(\mathrm{p}<0,05)$.

\section{KESIMPULAN DAN SARAN \\ Kesimpulan}

Berdasarkan penelitian yang dilakukan di Wilayah Puskesmas Simangalam Kabupaten Labuhanbatu Utara Tahun 2020 did apatkan kesimpulan :

1. Nyeri Dismenorea pada Remaja sebelum diberikan Kompres Air Hangat di Wilayah Puskesmas Simangalam Kabupaten Labuhanbatu Utara Tahun 2020 adalah sebagian besar nyeri sedang.

2. Nyeri Dismenorea pada Remaja sebelum diberikan Kompres Air Hangat di Wilayah Puskesmas Simangalam Kabupaten Labuhanbatu Utara Tahun 2020 adalah sebagian besar nyeri ringan.

3. Terdapat Pengaruh Pemberian Kompres Air Hangat terhadap Nyeri Dismenorea pada Remaja di Wilayah Puskesmas Simangalam Kabupaten Labuhanbatu Utara Tahun 2020 dengan nilai $p-0,0001<a=0,05$.

\section{Saran}

1. Tempat Penelitian

Diharapkan dengan adanya penelitian ini kader kesehatan yang ada di Wilayah Puskesmas Simangalam Kabupaten Labuhanbatu Utara turut serta memberikan edukasi tentang pentingnya pemberian kompres hangat dalam pengurangan nyeri.

2. Institusi Penelitian

Diharapkan dengan adanya penelitian ini akan menambah informasi dalam perkembangan ilmu pengetahuan khususnya mengenai kompres hangat dan nyeri haid.

3. Peneliti Selanjutnya 
Diharapkan bagi peneliti selanjutnya dapat menjadi referensi awal penelitian yang sama serta menambah variabel penelitian agar peneli semakin akurat

\section{DAFTAR PUSTAKA}

Andari, F, N, 2015. Pengaruh Pelatihan Peregangan Senam Ergonomis Terhadap Penurunan Skor Nyeri Muskuloskeletal Disorders (MSDs) Pada Perkerja Pembuat Kaleng Alumunium.

Andarmoyo, S dan Suharti, S. 2013. Persalinan Tanpa Nyeri ; Konsep Dan Aplikasi Manajemen Persalinan. Yogyakarta: Ar-Ruzz Media. Hal. 15- 55

Anugraheni, V dan Wahyuningsih,A. 2013.Efektifitas kompres hangat dalam menurunkan intensitas nyeri dysmenorrhoea. Kediri:Jurnal STIKES Baptis Volume 6, No. 1.

Anurogo, D \& Ari W. (2011). Cara Jitu Mengatasi Nyeri Haid. Yogyakarta: Andi

Nida, R.M dan Sari, D.F, 2016. Pengaruh Pemberian Kompres Hangat terhadap Penurunan Nyeri Dismenorea pada Responden Kelas XI SMK Muhammadiyah Watukelir Sukoharjo. Jurnal Kebidan dan Kesehatan Tradisional. Volume 1. Nomor 2.

Notoatmodjo, Soekidjo, 2014, Promosi Kesehatan dan Perilaku Kesehatan, Rineka Cipta, Jakarta

Notoatmodjo. 2010. Metodologi Penelitian Kesehatan. Jakarta : PT. Rineka Cipta

Nursalam, 2013. Metodologi Penelitian Ilmu Keperawatan: Pendekatan Praktis. Ediisi 3. Jakarta. Salemba Medika.

Nurwana, Sabilu, Y dan Fachlevy, A.F, 2017. Analisis Faktor yang Berhubungan dengan Kejadian Dismenorea pada Remaja Putri di SMA Negeri 8 Kendari Tahun 2016. Jurnal Ilmiah Mahasiswa Kesehatan Masyarakat. Volume 2. Nomor 6. ISSN : 250-731X.

Oktalina, L. Pemberian Slow Deep Breathing terhadap Penurunan Intensitas Nyeri pada Asuhan Keperawatan Ny. S dengan Pasa Operasi Ca. Bulli di Ruang Mawar RSUD Dr. Moewardi Surakarta. STIKes Kusuma Husada, Surakarta :

Patasik, C, K. Tangka, J. Rottie, J. (2013). Efektifitas Tehnik Relaksasi Nafas Dalam Dan Guided Imagery Terhadap Penurunan Nyeri Pada Pasien Post Operasi Sectio Caesarea Di Irina D BLU RSUP Prof.DR.R. D KANDOU Manado 